\title{
Peran Perawat Dalam Memberikan Edukasi Kepada Pasien Dan Keluarga Sebagai Partner Di Pelayanan Kesehatan Untuk Mencegah Terjadinya Bahaya Dan Adverse Events
}

\author{
Salsabila Nafi'ah \\ salsabnafiah@gmail.com
}

\section{Latar Belakang}

Keluarga merupakan unit paling dekat dengan pasien, dan merupakan perawat utama bagi pasien. Keluarga berperan dalam menentukan cara atau perawatan yang diperlukan pasien di rumah sakit. Keberhasilan perawat di rumah sakit akan sia-sia jika tidak diteruskan di rumah yang kemudian mengakibatkan pasien harus dirawat kembali (kambuh). Peran serta keluarga sejak awal perawatan di rumah sakit akan meningkatkan kemampuan keluarga merawat pasien di rumah sehingga memungkinkan pasien tidak kambuh atau dapat dicegah. Keluarga merupakan bagian dari tim pengobatan dan perawatan. Apalagi di Indonesia dengan kultur sosialnya tinggi ditambah keterbatasan jumlah perawat di rumah sakit sehingga tugas merawat orang sakit yang dirawat di rumah sakit umumnya dilakukan oleh keluarga yang menjaga. Para anggota keluarga menunggui secara bergantian, bahkan sering menjaga bersama-sama. Sementara perawat di rumah sakit yang seharusnya merawat orang sakit juga harus melakukan tugas-tugas yang lain di bangsal perawatan. Maka, peran keluarga penting untuk memantau kebutuhan pasien dari laporan perawat atau jika perlu malakukan komunikasi langsung.

Beberapa rumah sakit mengizinkan pasien untuk membawa alat komunikasi yang perlu digunakan. Hal ini juga terbukti dari hasil penelitian yang dilakukan di rumah sakit Amerika serikat bahwa dengan keterlibatan pasien maupun anggota keluarganya dalam merawat dan memberikan kesempatan kepada keluarga pasien untuk berkunjung ke rumah sakit lebih lama dapat menguragi resiko kecemasan yang berlebihan yang diderita oleh pasien. Tentunya hal ini dapat dirasakan jika penderita merasakan adanya dukungan sosial dari orang-orang sekitarnya, merasa dirinya dihargai, diperhatikan dan dicintai. Contohnya adalah bila ada seseorang yang sakit dan terpaksa di rawat di rumah sakit maka sanak saudara ataupun teman-teman biasanya datang berkunjung. Dengan kunjungan tersebut maka orang yang sakit atau pasien ini tentu merasa mendapat dukungan sosial sehingga secara tidak langsung dapat mempercepat kesembuhan 
Keluarga yang akan menerima penderita di rumah sepulang dari rumah sakit. Begitu siap dipulangkan keluarga menerima estafet pengelolaan penderita di rumah sebagai kelanjutan pengelolaan di rumah sakit. Karena itu selama di rumah sakit keluarga berhak atas informasi pengobatan, perawatan, dan penanganan lainnya terhadap penderita. Karena itu bertanya kepada pihak rumah sakit merupakan hak keluarga untuk memperoleh informasi tersebut. Keluarga perlu perlu mulai membuka dan menjalin 'kedekatan' dengan personel rumah sakit untuk keperluan ini

\section{Metode}

Metode yang digunakan untuk memperoleh informasi dan data yaitu menggunakan metode literasi membaca jurnal, buku, dan karya ilmiah lainnya.

\section{Hasil}

Melalui hasil literasi membaca jurnal, buku, dan karya ilmiah, didapatkan bahwa peran perawat dalam memberikan edukasi kepada pasien dan keluarga sebagai partner di pelayanan kesehatan untuk mencegah terjadinya bahaya dan adverse events sangatlah berperngaruh.

\section{Pembahasan}

Peningkatan mutu dalam segala bidang khususnya dalam bidang kesehatan salah satunya melalui akreditasi Rumah Sakit menuju kualitas pelayanan Internasional. Dalam sistem akreditasi yang mengacu pada standar Joint commission International (JCI) diperoleh standar yang paling relevan terkait dengan mutu pelayanan Rumah Sakit International Patient Safety Goals (sasaran international keselamatan pasien) yang meliputi enam sasaran keselamatan pasien rumah sakit. (Kemenkes RI, 2011). Keselamatan Pasien (Patient Safety) merupakan sesuatu yang jauh lebih penting dari pada sekedar efisiensi pelayanan. Perilaku perawat dengan kemampuan perawat sangat berperan penting dalam pelaksanaan keselamatan pasien.

Perilaku yang tidak aman, lupa, kurangnya perhatian/motivasi, kecerobohan, tidak teliti dan kemampuan yang tidak memperdulikan dan menjaga keselamatan pasien berisiko untuk terjadinya kesalahan dan akan mengakibatkan cedera pada pasien, berupa Near Miss (Kejadian Nyaris Cedera/KNC) atau Adverse Event (Kejadian Tidak Diharapkan/KTD) selanjutnya pengurangan kesalahan dapat dicapai dengan memodifikasi perilaku. Perawat harus melibatkan kognitif, afektif dan tindakan yang mengutamakan keselamatan pasien. World Health 
Organization (WHO), 2014 Keselamatan pasien merupakan masalah keseahatan masyarakat global yang serius. Di Eropa mengalami pasien dengan resiko infeksi 83,5\% dan bukti kesalahan medis menunjukkan 50-72,3\%. Di kumpulkan angka-angka penelitian rumah sakit di berbagai Negara, ditemukan KTD dengan rentang 3,2 - 16,6\%.

Data Patient Safety tentang Kejadian Nyaris Cedera (KNC) dan Kejadian Tak Diharapkan (KTD) di Indonesia masih jarang, namun dipihak lain terjadi peningkatan tuduhan "mal praktek" yang belum tentu sesuai dengan pembuktian akhir. Insiden pelanggaran patient safety 28,3\% dilakukan oleh perawat. Bawelle, 2013 secara keseluruhan program patient safety sudah diterapkan, namun masalah dilapangan merujuk pada konsep patient safety, karena walaupun sudah pernah mengikuti sosialisasi, tetapi masih ada pasien cedera, resiko jatuh, resiko salah pengobatan, pendelegasian yang tidak akurat saat oforan pasien yang mengakibatkan keselamatan pasien menjadi kurang maksimal.

\section{A. Peran keluarga secara aktif dalam menjaga keselamatan pasien dipelyanan kesehatan adalah}

1. Memberikan informasi yang benar, jelas, lengkap dan jujur

2. Mengetahui dan melaksanakan kewajiban serta tanggung jawab pasien maupun keluarga.

3. Mengajukan pertanyaan-pertanyaan untuk hal yang tidak dimengerti.

4. Memahami dan menerima konsekuensi pelayanan.I

5. Mematuhi dan menghormati peraturan rumah sakit.

6. Memperlihatkan sikap menghormati dan tenggang rasa dalam proses bersama tim kesehatan mengelola pasien

7. Memenuhi kewajiban finansial yang disepakati. 


\section{B. Penerapan enam sasaran keselamatan pasien dan peran keluarga dalam menjaga keselamatan pasien di pelayanan kesehatan}

\section{Ketepatan Identifikasi Pasien}

Pasien dalam keadaan tidak sadar, gelisah, mengalami gangguan penglihatan, gangguan pendengaran, gangguan proses pikir, mendapat obat bius, atau gangguan lain tidak mampu melakukan identifikasi diri dengan benar selain itu pasien yang pindah ruang rawat atau bertukar tempat tidur saat perawatan di rumah sakit berisiko mengalami ketidaktepatan identifikasi, maka rumah sakit menyusun sistem untuk memastikan identifikasi pasien sebagai individu yang akan menerima pelayanan adalah tepat dan jenis pelayanan atau pengobatan terhadap individu tersebut adalah sesuai.

\section{Peran Pasien dan keluarga untuk memastikan ketepatan identifikasi pasien adalah:}

a. Memberikan data diri yang tepat pada saat mendaftar sesuai dokumen data diri yang dimiliki. Data utama yang diperlukan adalah nama dan tanggal lahir

b. Selama rawat inap pasien dipakaikan gelang. Pasien dan keluarga harus memahami fungsi gelang dan patuh menggunakan gelang tersebut selama rawat inap karena gelang tersebut dipakai oleh tim kesehatan guna memastikan kebenaran identitas dan faktor risiko pasien saat memberikan pelayanan.

$\checkmark$ Gelang warna biru untuk laki-laki dan gelang warna merah muda untuk perempuan dipakai untuk identifikasi

$\checkmark$ Gelang warna merah dipasangkan pada pasien yang memiliki riwayat alergi

$\checkmark$ Gelang warna kuning dipasangkan pada pasien yang memiliki risiko jatuh

c. Pasien atau keluarga kooperatif saat dilakukan verifikasi identitas oleh petugas saat akan melakukan tindakan, memberikan obat, mengambil preparat untuk pemeriksaan laborat dan lainlain.

\section{Komunikasi efektif}

Pasien yang menjalani rawat inap dikelola oleh dokter dan berbagai profesi lain sebagai tim dengan menerapkan sistem komunikasi yang efektif untuk memberikan pelayanan 


\section{Peran pasien dan keluarga mewujudkan komunikasi efektif adalah:}

a. Menunjuk atau menetapkan anggota keluarga yang diberi kewenangan untuk berkomunikasi dengan tim kesehatan. Penunjukkan ini diperlukan untuk memastikan komunikasi berlangsung efektif dan berkesinambungan, tidak mengalami rantai komunikasi yang panjang dan kompleks yang berisiko menyebabkan perubahan makna isi informasi.

b. Memberikan informasi dan data terkait kondisi pasien kepada tim kesehatan dengan benar dan jelas.

c. Memberikan informasi pada petugas bila ada kejadian tidak diharapkan.

d. Meminta informasi yang diperlukan kepada tim kesehatan

\section{Pemberian obat secara aman}

Pemberian obat merupakan bagian yang mengambil porsi dominan dalam tata kelola pasien rawat inap..

Peran serta keluarga dalam menjamin keamanan pemberian obat adalah

a. Memberikan informasi yang lengkap tentang riwayat obat yang pernah dipergunakan sebelum masuk rumah sakit

b. Memberikan informasi tentang riwayat alergi atau reaksi yang dialami saat menggunakan obat tertentu

c. Mendukung pengawasan pemberian obat selama rawat inap dengan cara memastikan identitas pasien benar, menanyakan jenis obat yang diberikan, tujuan pemberian, dosis dan waktu pemberian obat

\section{Kepastian Tepat-Lokasi, Tepat-Prosedur, Tepat-Pasien Operasi}

Tindakan operasi merupakan salah satu prosedur yang mungkin dilakukan pada pasien untuk mengatasi masalah kesehatannya. Bagian tubuh yang akan dioperasi bisa meliputi bagian yang bersisi (misalnya tangan atau kaki kanan dan kiri, mata kanan dan kiri) atau bagian yang multipel level (misalnya tulang belakang) ataubagian yang multipel struktur (misalnya jari tangan) dengan demikian diterapkan sistem untuk memastikan tindakan tepat-lokasi, tepat-prosedur, tepat- 
pasien Salah satu prosedur yang dilakukan sebelum tindakan operasi adalah proses verifikasi. Peran pasien dan keluarga dalam proses verifikasi praoperasi adalah memberikan informasi yang benar dan bekerja sama secara kooperatif Proses yang dilakukan meliputi

a. Verifikasi lokasi, prosedur, dan pasien yang benar Proses ini dilakukan dengan membuat tanda pada lokasi yang dioperasi. Penandaan lokasi operasi ini melibatkan pasien, dibuat oleh dokter yang akan melakukan tindakan dan dilaksanakan saat pasien dalam keadaan sadar .Tanda ini tidak boleh dihapus dan harus terlihat sampai saat akan disayat.

b. Memastikan bahwa semua dokumen, foto (imaging), hasil pemeriksaan yang relevan tersedia, diberi label dengan baik

c. Melakukan verifikasi ketersediaan peralatan khusus yang dibutuhkan.

\section{Pengurangan risiko infeksi terkait pelayanan kesehatan}

Rumah sakit merupakan tempat yang memungkinkan berkumpulnya berbagai jenis kuman sedangkan pasien yang sedang dirawat memiliki daya tahan tubuh relatif rendah dengan demikian diperlukan suatu proses bersama untuk mencegah timbulnya infeksi lain yang tidak berhubungan dengan penyakit utama pasien Peran pasien dan keluarga dalam pengurangan risiko terkait pelayanan Kesehatan adalah

a. Menerapkan prosedur cuci tangan yang benar

Keluarga memiliki kemungkinan sering kontak dengan pasien, maka untuk melindungi diri sendiri dan melindungi pasien dari perpindahan kuman disarankan keluarga menerapkan prosedur cuci tangan yang benar pada 5 (lima) momen yaitu saat sebelum kontak dengan pasien, sesudah kontak pasien, sesudah ke toilet, sebelum dan sesudah makan. Perlu diperhatikan juga bahwa lingkungan sekitar pasien berisiko terpapar kuman maka disarankan mencuci tangan sesudah kontak dengan lingkungan pasien (meja, alat tenun, tempat tidur dsb), Guna memperoleh hasil cuci tangan yang optimal Pasien dan keluarga disarankan mencermati dan mengikuti petunjuk 6 (enam) langkah mencuci tangan yang diberikan oleh petugas atau panduan cuci tangan yang ada di rumah sakit 
b. Membatasi pengunjung pasien

Selama pasien dirawat di rumah sakit seyogyanya pasien tidak berinteraksi dengan banyak orang karena berisiko terpapar kuman dari pengunjung dalam keadaan pertahanan diri yang relatif rendah dengan demikian peran keluarga diperlukan untuk membatasi pengunjung yang kontak dengan pasien

c. Menerapkan etika batuk yang benar

Keluarga dan pengunjung yang batuk berisiko menyebarkan kuman melalui partikel halus di udara dengan demikian bila sedang mengalami batuk keluarga perlu menggunakan masker atau menerapkan tehnik perlindungan yang benar saat batuk yaitu menutup mulut dan hidung menggunakan lengan.

\section{Pengurangan Risiko Pasien Jatuh}

Individu yang sedang sakit memiliki keterbatasan dalam pengamanan diri termasuk menghindari jatuh. Rumah sakit mengambil tindakan untuk mengurangi risiko dengan melakukan pengkajian faktor-faktor yang dapat menyebabkan jatuh seperti, penggunaan obat, gaya jalan dan keseimbangan, alat bantu berjalan yang digunakan oleh pasien, riwayat jatuh saat berjalan atau saat istirahat baring di tempat tidur.

\section{Peran pasien dan keluarga dalam mencegah jatuh saat dirawat di rumah sakit adalah}

a. Pastikan penanda pasien beresiko jatuh berupa gelang kuning dipakai pasien

b. Jangan melepas atau memindah kartu kuning yang dipasang petugas dekat tempat tidur pasien atau di depan kamar pasien karena kartu tersebut merupakan penanda untuk mewaspadai pasien yang beresiko jatuh

c. Keluarga atau pasien perlu memastikan diri untuk memahami informasi yang diberikan oleh petugas agar dapat mendukung tindakan pencegahan jatuh. Informasi yang perlu diketahui adalah:

$\checkmark$ Faktor resiko jatuh yang teridentifikasi seperti obat yang dipergunakan, kesadaran pasien, keseimbangan saat berjalan,dll

$\checkmark$ Tindakan pencegahan jatuh yang perlu dilakukan 


\footnotetext{
$\checkmark$ Cara untuk minta bantuan

$\checkmark$ Cara menggunakan bel atau sarana komunikasi di ruangan

$\checkmark$ Cara mengatur pengamanan tempat tidur

$\checkmark \quad$ Pengggunaan tali pengaman, dll
}

\section{Kesimpulan}

Keselamatan pasien adalah bebas dari cidera aksidental atau menghindarkan cidera pada pasien akibat perawatan medis dan kesalahan pengobatan . Keselamatan pasien rumah sakit adalah suatu sistem dimana rumah sakit membuat asuhan pasien lebih aman (Dep Kes RI, 2006). Keselamatan pasien merupakan suatu sistem untuk mencegah terjadinya cedera yang disebabkan oleh kesalahan akibat melaksanakan suatu tindakan atau tidak mengambil tindakan yang seharusnya diambil (TKPRS RSUP Sanglah Denpasar, 2011). Taylor, et al. (1993) mengungkapkan bahwa keperawatan merupakan profesi yang berfokus kepada pelayanan dan bertujuan membantu pasien mencapai kesehatannya secara optimal. Oleh karena itu pada saat memberikan asuhan keperawatan kepada pasien, perawat harus mampu memastikan bahwa pelayanan keperawatan yang diberikan mengedepankan keselamatan. Perawat harus memiliki kesadaran akan adanya potensi bahaya yang terdapat di lingkungan pasien melalui pengidentifikasian bahaya yang mungkin terjadi selama berinteraksi dengan pasien selama 24 jam penuh, karena keselamatan pasien dan pencegahan terjadinya cedera merupakan salah satu tanggung jawab perawat selama pemberian asuhan keperawatan berlangsung. 


\section{Daftar Pustaka}

1. Febrina, W. (2018). Analisis Peran Keluarga sebagai Pengawas Minum Obat (PMO) Pasien TB Paru. Human Care Journal, 3(2), 118-129

2. Ismainar, H. (2015). Keselamatan Pasien di Rumah Sakit. Deepublish.

3. Jufrizal, J., Hermansyah, H., \& Mulyadi, M. (2016). Peran Keluarga Sebagai Pengawas Minum Obat (Pmo) Dengan Tingkat Keberhasilan Pengobatan Penderita Tuberkulosis Paru. Jurnal IImu Keperawatan, 4(1).

4. Kusumaningrum, T., Pradanie, R., Yunitasari, E., \& Kinanti, S. (2016). Peran Keluarga dan Kualitas Hidup Pasien Kanker Serviks. jurnal ners, 11(1), 112-117.

5. Lombogia, A., Rottie, J., \& Karundeng, M. (2016). Hubungan Perilaku Dengan Kemampuan Perawat Dalam Melaksanakan Keselamatan Pasien (Patient Safety) Di Ruang Akut Instalasi Gawat Darurat RSUP Prof. Dr. RD Kandou Manado. Jurnal Keperawatan, 4(2).

6. Maulidia, D. F. (2014). Hubungan antara dukungan keluarga dan kepatuhan minum obat Pada penderita Tuberkulosis Di wilayah Ciputat Tahun 2014.

7. Nursalam, D. K., \& Dian, N. (2007). Asuhan keperawatan pada pasien terinfeksi HIV. Jakarta: Salemba Medika.

8. Prasetyo, A., \& Syaifudin, S. (2013). Hubungan Patient Sefety dengan Kepuasan Pelanggan di Ruang Rawat Inap Rumah Sakit Jiwa Grahasia PEMDA DIY(Doctoral dissertation, STIKES'Aisyiyah Yogyakarta).

9. Pujilestari, A., Maidin, A., \& Anggraeni, R. (2013). Gambaran Budaya Keselamatan Pasien Oleh Perawat Dalam Melaksanakan Pelayanan Di Instalasi Rawat Inap RSUP Dr. Wahidin Sudirohusodo Tahun 2013. Jurnal Kesehatan Masyarakat, 1-13.

10. Salawati, L. (2020). Penerapan keselamatan pasien rumah sakit. AVERROUS: Jurnal Kedokteran dan Kesehatan Malikussaleh, 6(1), 98-107.

11. Simamora, R. H. (2019). Buku ajar pelaksanaan identifikasi pasien. Uwais Inspirasi Indonesia.

12. Wulandari, S. (2019). ASUHAN KEPERAWATAN KELUARGA PADA PASIEN TB PARU DENGAN MASALAH KEPERAWATAN KETIDAKPATUHAN MINUM OBAT Di Wilayah Kerja Puskesmas Sukorejo Kabupaten Ponorogo (Doctoral dissertation, Universitas Muhammadiyah Ponorogo). 